研究ノート

洪德均田例に関する史料紹介(2)

桜井由躬雄

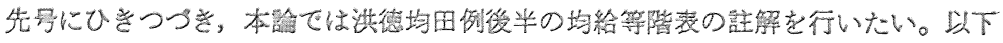

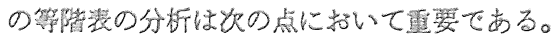

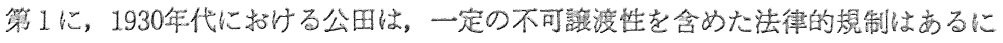

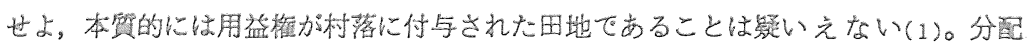

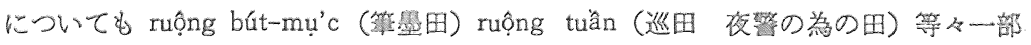

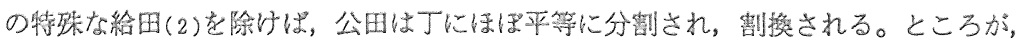

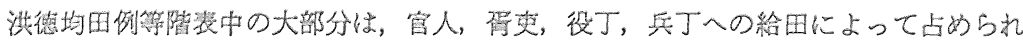
る。これは中世公田が，近世公田と翼なり，国有的色彩を灌厚に有していたこと赤 している。

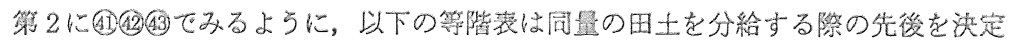
する镜味があったと考光られる。とすれば、この㳖の分析は従来ヴェトナムの村落社

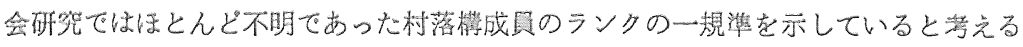
ことがでさら。

これらの分析は、詳細をすでに失なった他の律令国家群の均田秩序の理解に一定の

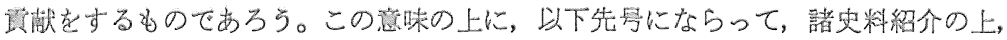
各事項の韸解起行いたい。

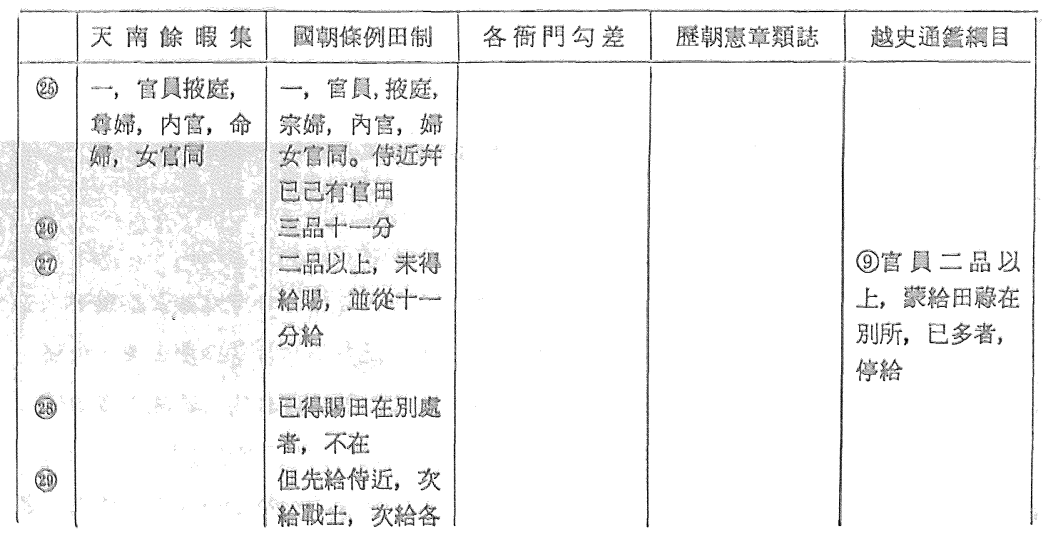




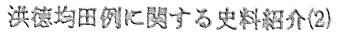

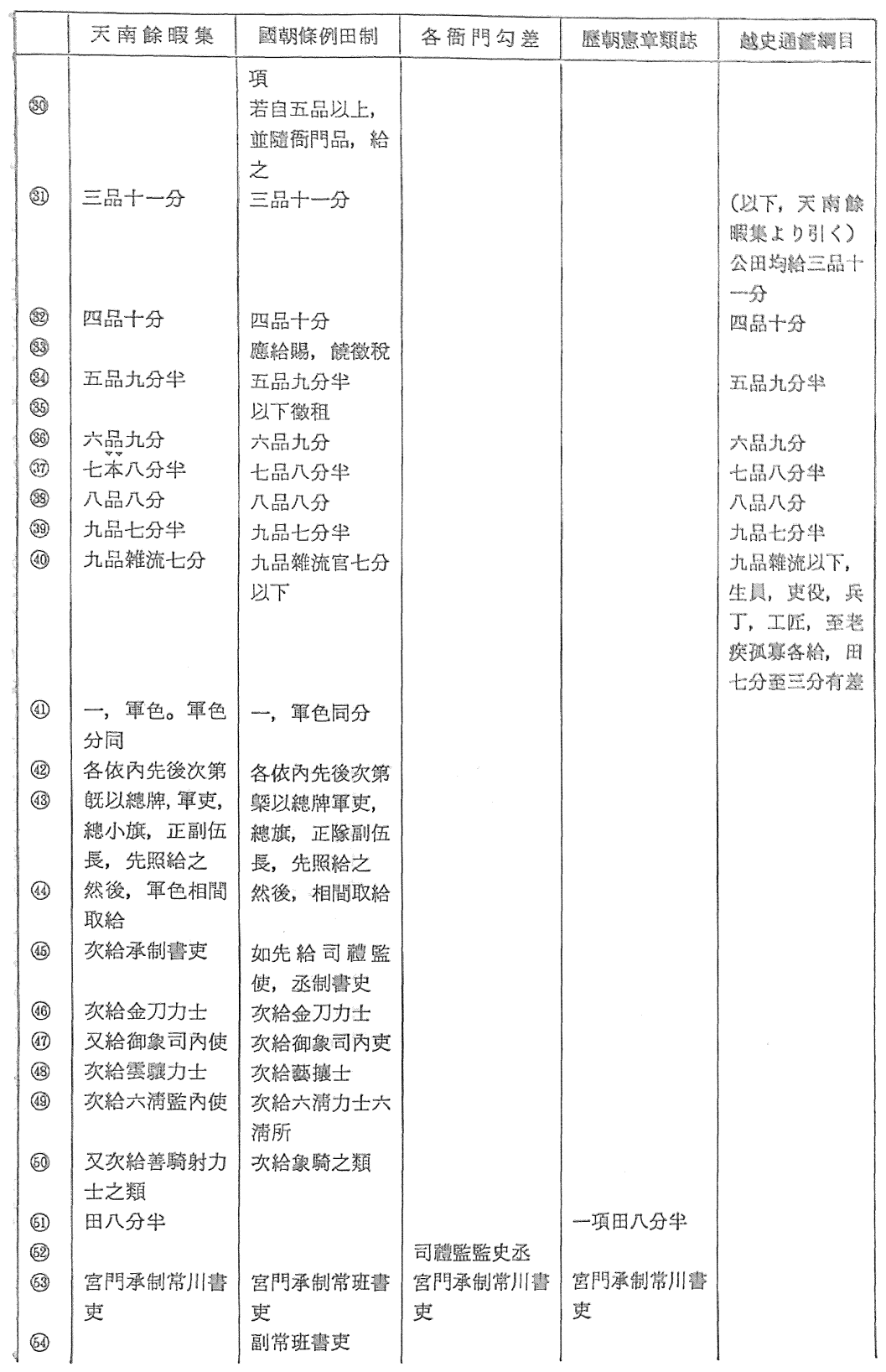




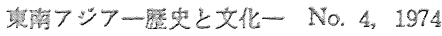

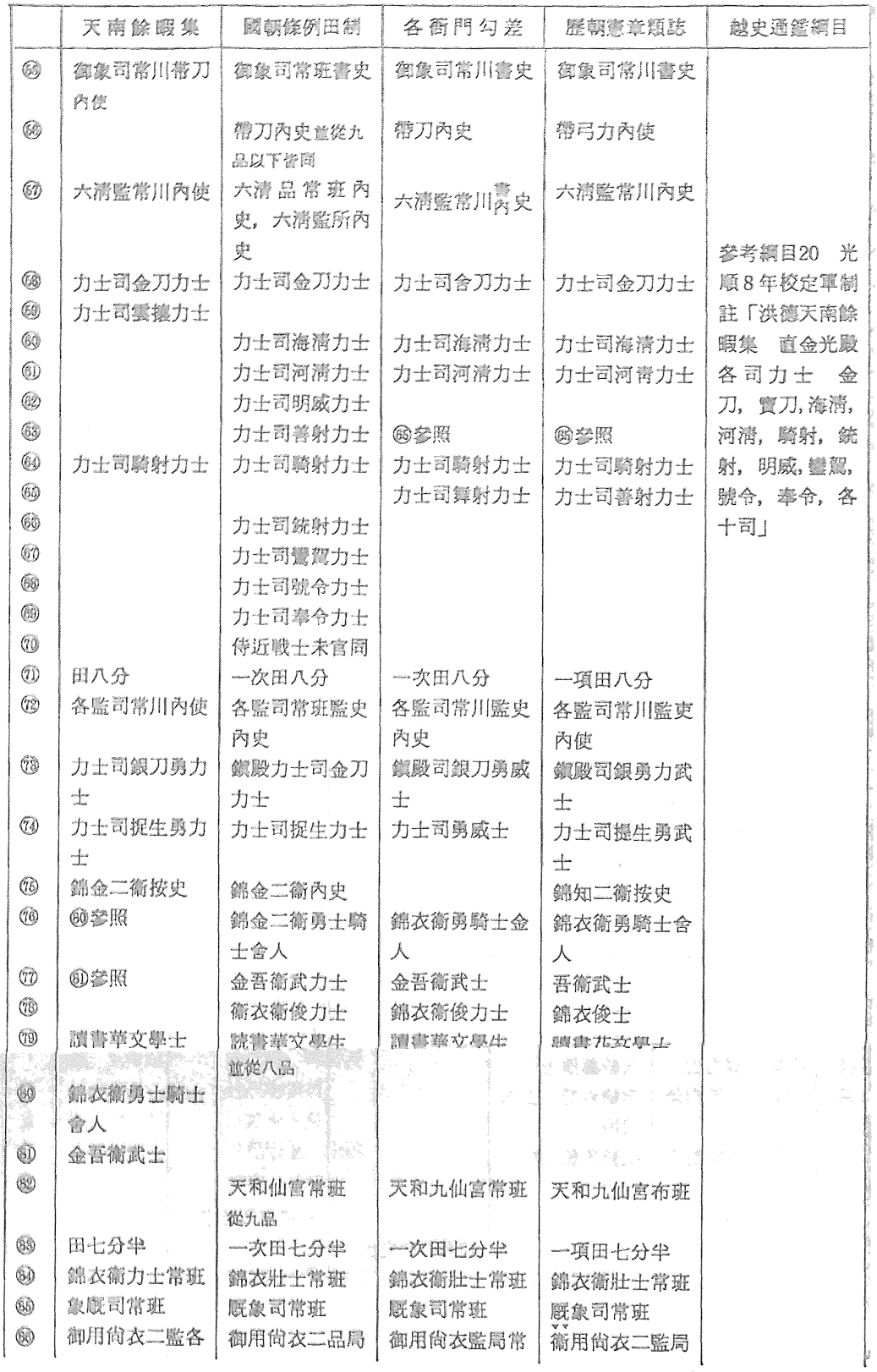




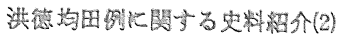

\begin{tabular}{|c|c|c|c|c|c|}
\hline & 天南餘暇賲 & 國朝條例田制 & 各简門勾逵 & 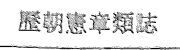 & 越史通嘰細目 \\
\hline (30) & $\begin{array}{l}\text { 局常班 } \\
\text { 工部各恠常班 }\end{array}$ & 常班前從九品 & 班 & 常班 & \\
\hline (3) & 由七分 & 一次田七分 & 一次田七分 & 一项田七行 & \\
\hline (2) & 鎳衣衛艇騎壯士 & 錦衣政飛踦壯力 & 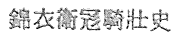 & 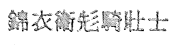 & \\
\hline (9) & 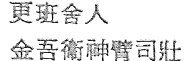 & 集班会人 & 史斑金人 & 英壦禽人 & \\
\hline & 士 & 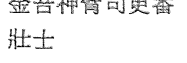 & (3)经照 & 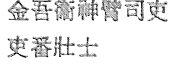 & \\
\hline (91) & 效力四筬 & 效力四衡 & 效力白榴 & 效力四衙 & \\
\hline $\begin{array}{l}\text { (92) } \\
\text { (3) }\end{array}$ & 神珷四盛 & 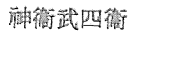 & 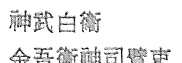 & 触武四簿 & \\
\hline & & & 澢壯士 & & \\
\hline (24) & & 炣林衙 & 炣井旒 & 武䅦衔 & \\
\hline (25) & 錦衣䘖各司壯士 & 錦衣各羭司力士 & 錦衣各司壯士 & 鐡各间壯士 & \\
\hline (96) & 皘前司六筬 & 殿前司五愬 & 殿前司互衔 & 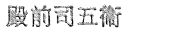 & \\
\hline (19) & 硻眼司常班 & 既酸常班 & 熙筑司尚班 & 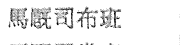 & \\
\hline (28) & & 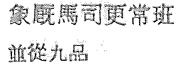 & 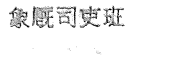 & 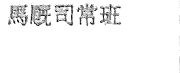 & \\
\hline (99) & 中城兵婜司 & 中城郎將兵馬司 & & 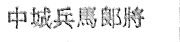 & \\
\hline (10i) & 㟈文館価生 & 祘交館曙生 & 实交館虂生 & 紫文龍筑生 & \\
\hline (10i) & 在內各衙門常班 & 在內各镱門都題 & 在內各唯門都籍 & 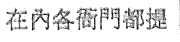 & \\
\hline & & 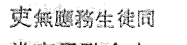 & 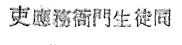 & 吏 & \\
\hline (10) & 國子監舍生 & 常班子監舍人 & & & \\
\hline (10) & 时六分牛 & 一次田六分牛 & 一次田六分本 & 一项田仧分斗 & \\
\hline (104) & 婜厩司更班 & 馬既司更常班 & 篤穊河更班 & 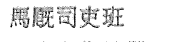 & \\
\hline (105) & 五軍各拊衞睦霓 & 五軍各衞踦微 & 五府各衔緻男 & 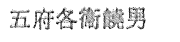 & \\
\hline (100) & 四城兵馬司 & 四城兵麗郎將 & 四城兵婜郎將 & 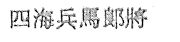 & \\
\hline (10i) & 田六分 & 一次田六份 & 一次田六分 & 一顷目六分 & \\
\hline (10. & 五府各衛 & 五車苻各衛 & 五軍各衛 & 五军条街 & \\
\hline (20) & 馿毁四衡 & 剽敌四䚘 & 跨像自細 & 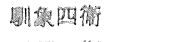 & \\
\hline (11i) & 瑟闑徱 & 馬闗衔 & 䭴同盛 & 馬闌呬衡 & \\
\hline (iii) & 在外各语門常班 & 在外各䩹門题束 & 在外衙門筐䣒 & 在外各衙閣提吏 & \\
\hline & & 然盟婘生起闰 & 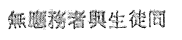 & 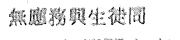 & \\
\hline (11) & 在內各衙門面班 & 在外各衙門車常 & 在內各衙門曹班 & 在外各语閒现班 & \\
\hline & & 班束 & & 茰 & \\
\hline (113) & 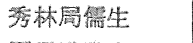 & 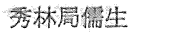 & 唀林鼠船生 & 等株局僄生 & \\
\hline (11) & 國子監監生 & & & & \\
\hline (115) & 啁正 & 龍正 & 社正 & 能舆 & \\
\hline (116) & 隔实 & 䟩史 & 融史 & 骮史 & \\
\hline (ii) & 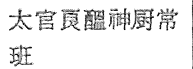 & 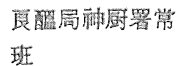 & 隹达照 & 19趝照 & \\
\hline (118) & 宣璥局 & 薑達局大官啫 & 宣 & 宦選掘 & \\
\hline (119) & (111)照照 & （11D)望照 & 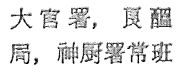 & 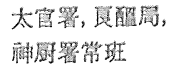 & \\
\hline
\end{tabular}




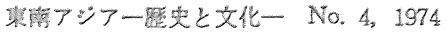

\begin{tabular}{|c|c|c|c|c|c|}
\hline & 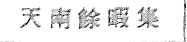 & 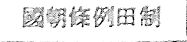 & 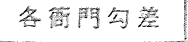 & 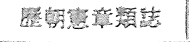 & 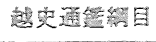 \\
\hline$(4)$ & 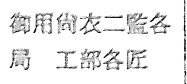 & 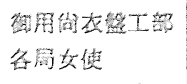 & 微用淂长案各属 & 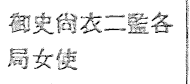 & \\
\hline (2) & 9日. I. 手 & 一次田五分里 & 一次䁌五分里 & 一㙋由五分牛 & \\
\hline 10 & 在外各衡而 & & 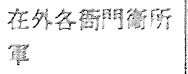 & 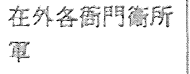 & \\
\hline 12 & 座在各街斯 & 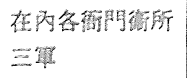 & 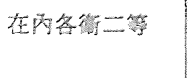 & 在丙各鼠三滗 & \\
\hline 20 & 各街问間军 & 各司衔刻聚 & 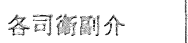 & 各司澎得軍 & \\
\hline 2 & 五刑同獾卒 & 五刑司獾所 & 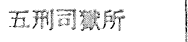 & 琣刑司獤所 & \\
\hline 6 & 它貝父 & 寔貝父 & 官虽父 & 宫員父 & \\
\hline 9 & $\begin{array}{l}\text { 在外各衙阿笨班 } \\
\text { 䗡 }\end{array}$ & 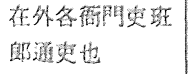 & 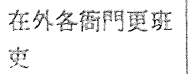 & 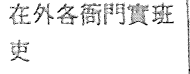 & \\
\hline 12 & 能碍 & 能䅞 & 骮增 & 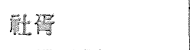 & \\
\hline (2) & 官買子称 & 管员子孫 & 它只子㗪 & 官包子孫 & \\
\hline 30 & 生铅 & 生徤 & 生徒 & 生起 & \\
\hline (3) & 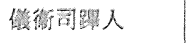 & 䈏微闰 & 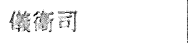 & 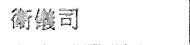 & \\
\hline 3 & 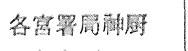 & 各營箸局痈人 & 各官署桪㷉人 & 各宦涟局䝰人 & \\
\hline (93) & 工部各呱 & 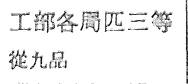 & 工部各呞二等 & 工部各呞二等 & \\
\hline (32) & 雅樂同交罢 & 雅樂同政二翼 & 雅樂同交二置 & 雅樂一䕎 & \\
\hline (3) & 侍衛呞 & 侍赦筍 & 侍箱闖 & 侍衙夙 & \\
\hline (3i) & 帮滇軍 & 费侍五軍 & 费監軍 & 奉渎镍算 & \\
\hline (31) & 教第節始 & 孝悌節媂 & 攀俤 節媒 & 節賈 莩弟 & \\
\hline 3 & 百戲所常理 & 百战所所常班 & 百齔所班 & 百齜所斑 & \\
\hline (39) & 在外各監同开偄 & 在外各監司㐫使 & 外各監网史監 & 外各監司內史監 & \\
\hline & 䉯便 & 筑使 & & 史 & \\
\hline (14) & 田五分 & 一次旺五分 & 一次田五分 & 一項田五分 & \\
\hline (41) & 在外各徱所二䇛 & 在外各衛所軍 & 在外各衞所軍 & 在外各衙所軍 & \\
\hline (41) & 膲慗呞 & 㮣教征 & 憵事呞 & 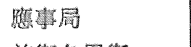 & \\
\hline (4) & 守衔各司衛軍 & 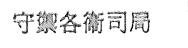 & 守衛各柌衛 & 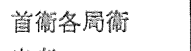 & \\
\hline (14) & & & 出老 & 出老 & \\
\hline (44) & & & 典棏同 & 四㕌司 & \\
\hline (140) & (15i)詓照 & & & 四摆局 & \\
\hline (4i) & 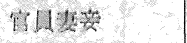 & 官具㳊努 & & & \\
\hline (6) & 藏京辟条偲 & 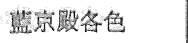 & 監宗殿各色 & 盖富没各色 & 残 \\
\hline (19) & 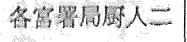 & & & & \\
\hline$x$ & 筫 & & & & \\
\hline (19) & 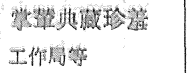 & & & & \\
\hline (5) & 典䐦所 & & & & \\
\hline (1932 & 內外各衙䦦照 & 內外各衙門等 & 在內各衡門䈍 & 在內各微門腽差 & \\
\hline & 美, 张恙, 承使 & 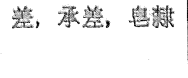 & $\begin{array}{l}\text { 美, 承使, 承登, } \\
\text { 息䍮 }\end{array}$ & 使 承差舁㤹 & \\
\hline
\end{tabular}




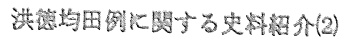

\begin{tabular}{|c|c|c|c|c|c|}
\hline & 天南鮽㗇策 & 國朝攸例回制 & 各简閏勾差 & 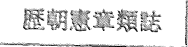 & 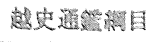 \\
\hline (5) & 田四分半 & 一次田四分斗 & 一次国四分乐 & 一增田四行牛 & \\
\hline (95) & 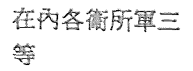 & $\begin{array}{l}\text { 在內各衟二等各 } \\
\text { 色 }\end{array}$ & 在內各橴算三等 & 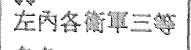 & \\
\hline 195 & 各色三等 & 㐿参照 & 各色三等 & 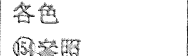 & \\
\hline (3. & 道士 & 道士 & 道士 & $\begin{array}{l}\text { brser } \\
\text { 造士 }\end{array}$ & \\
\hline (5) & 百䶢所人 & 百䶢所人数坊河 & 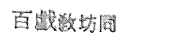 & 百戲所 人 & \\
\hline 5 & 道澧 & 道同 & 道成 & 邀弪 & \\
\hline (199) & 配人 & 蒜人 & 嗮人 & 㿢人 & \\
\hline (3) & 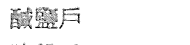 & 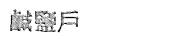 & 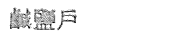 & 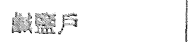 & \\
\hline (16) & 諸梲戶 & 訿例戶 & 暗祬月 & 嘴税月 & \\
\hline 这 & 江開守把人 & 江守官 肥簕 & 江守把笚 & 江管称把对 & \\
\hline (16) & 䌩巵 & 繢戶 & 解戸 & 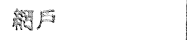 & \\
\hline (66) & 漁田 & 漁戸 & 濕戶 & 漁户 & \\
\hline 6 & 俞戶 & 禹户 & AF & 雨户 & \\
\hline 16 & 陵曰 & 陵戸 & 璣户 & 淢户 & \\
\hline 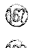 & 牧婜場索人 & 牧筍 㵋京人 & & 牧熙坦涼人 & \\
\hline$\Leftrightarrow$ & 明四分 & 一次田四分 & 一次时四分 & 一开四四分 & \\
\hline (6) & 在外各衞所寞三 & 在外各衡門所䇲 & 在外各衙門所霍 & 在外各衙門所箯 & \\
\hline (70) & 等 & 三等 & 三等 & $\equiv$ & \\
\hline (iii) & 舖夫 & 舖夫 & 檑失 & 胔夫 & \\
\hline (1ii) & 館驛夫 & 馆琵夫 & 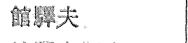 & 館役夫 & \\
\hline (1979 & 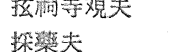 & 塭茼䏤寺觀夫 & 培洞寺觀夫 & 㹡沟等㛭执夫 & \\
\hline (114) & 湮夫 & 探絸夫 & $\begin{array}{l}\text { 探學 } \\
\text { 池澊 }\end{array}$ & 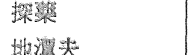 & \\
\hline (719) & 庫夫 & 陣夫 & 戝夫 & 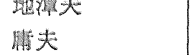 & \\
\hline (102) & 軍出 & 軍內 & & & \\
\hline (1ii) & 軍色男 & 軍色男 & 軍色男 & 簐色男 & \\
\hline 188 & 無色優你丁问 & 無色夏免丁阁 & 然色贺丁园 & 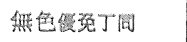 & \\
\hline (779); & 渡夫 & 渡夫 & 渡夫 & 慥夫 & \\
\hline (BD) & 策色淒妾夫然田 & 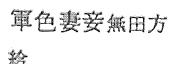 & 政色婆娈 & 㷅色选管 & \\
\hline (81) & 除賜稅人 & 除賜触人 & 除陽稅人 & 除䝮稅人 & \\
\hline 192 & 障人女丁睍受田 & 與人女丁尸涭官 & 興人女丁 & 與人奵丁 & \\
\hline 邀 & I, 足行停絵 & 田，足分停給 & & & \\
\hline (34) & 田三分牛 & 一次田三分牛 & $\begin{array}{l}\text { 一次田三分坐 } \\
\text { 不具. }\end{array}$ & $\begin{array}{l}\text { 一留目三分牛 } \\
\text { 不具 }\end{array}$ & \\
\hline (3) & $\begin{array}{l}\text { 不具 } \\
\text { 戴丁十七政以下 }\end{array}$ & 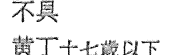 & $\begin{array}{l}\text { 不其 } \\
\text { 黄丁十七䶡以上 }\end{array}$ & 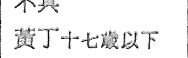 & \\
\hline (B) & 老分十五站以上 & 老分十齣以上 & & 老六线以上 & \\
\hline (18) & 偖惯 & 整役 & 傮倩 & 健传 & \\
\hline (Bis) & 徒各丁役邦同 & 徒丁役䛍同 & 徒各丁䘽铲阔 & 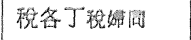 & \\
\hline (19) & 田三分 & 一次田三分 & 一次田三分 & 一㯃田三分 & \\
\hline (99) & 篦疾 & 簡廢 & 篤渗 & 籍嚓 & \\
\hline (911) & 殘疾 & 證突 & 殘垁 & 瀮突 & \\
\hline
\end{tabular}




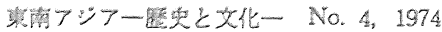

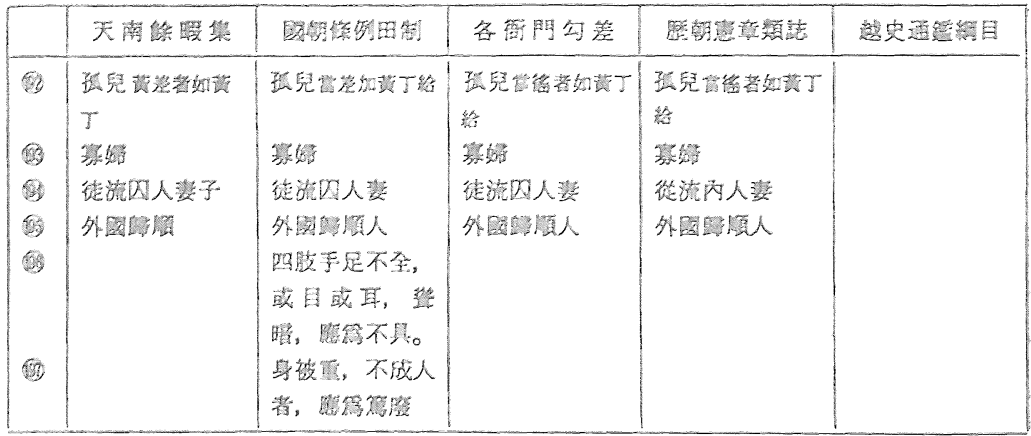

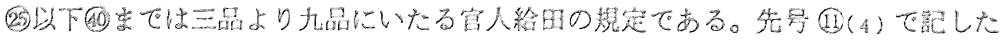

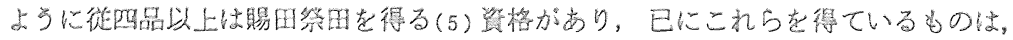
(9)によって緰せられないことになっている。したがって, 䋍目(6)(9)(11)で解するよう

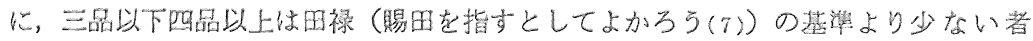
に対して支給されたと考えてよかるう。

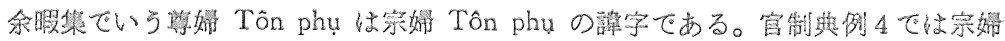
となっている。また同菁には命嫦とあり，田制では命が脱落したと考えるべきである

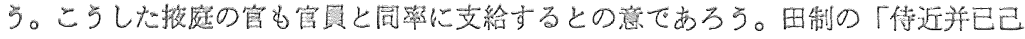
有官田」の意は不道であるが，先号(16)註解に引用する锗文例に照らせば，「停給」が 脱落していると考えられよう。侍近は後にひく例よりみて内官の湆かとも思われるが、

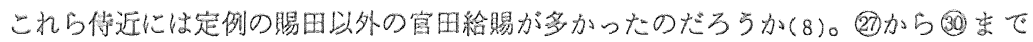

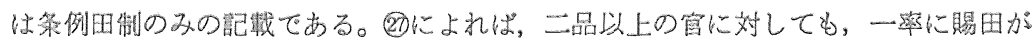
給されたわけではないこと走している。

(2) (9)包と此軗すると,「不在」は「停給」の意と考えるべきであろう。

凤は官人内部の給田順位と思われる。同一勘の給田でも分給の先後によって，不公

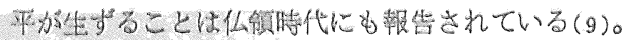

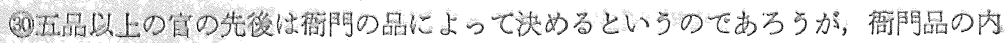

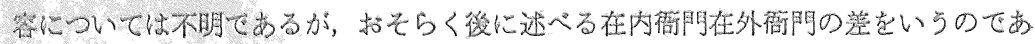
35.

\section{(31)(2) 当略。}

(33四品以上で踷田走給すべを者には，その代りとして得た給田についても，徵税を

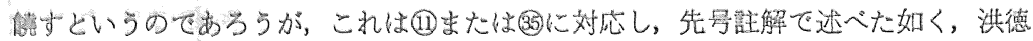

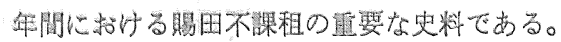




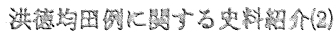

(34) 造省略。

(41)(42) 軍色で分同じものは各分内の先後次第によって給世よとある。これから、 (10以

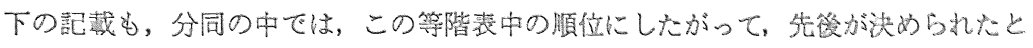
考えるべきであろう。

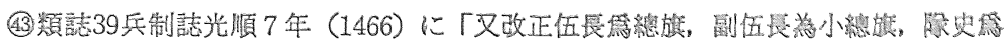
军吏」とある。43にいう總牌はこの總旗のことであり, 總小旗, 總旗は小總旗のこと と考えるべきであろう(10)。しかし，1466に廃されたはずの正副任罢が，總旗，總小 旗と並立しているのは不明である。まだこの時期には正副伍舆が残されていない罗も あったと侾えるべきだろうか。

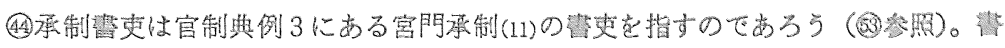
吏については類誌19釭選洪德公年「定各衙門吏㗄格出身例」に詳しい(12)。时制のみ に司礼監使の名がみえる。司礼監は宫制典例 3 にその名がみ光が，(52)勾选は司礼監

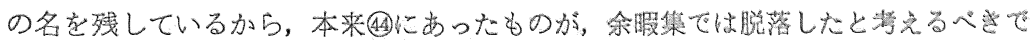

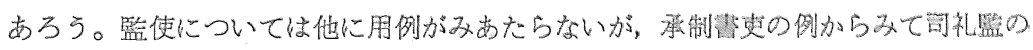

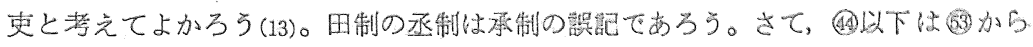

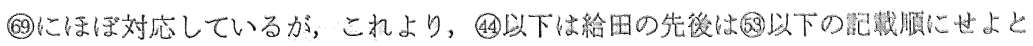

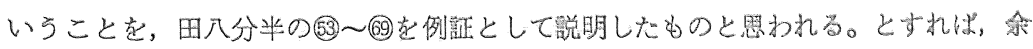
暇策でいう「次給」より田制の「如先給」が文意としては通じる。

(46)〜(50)は(52)〜70で述べ。

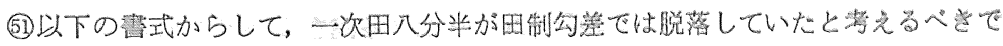
あろら。

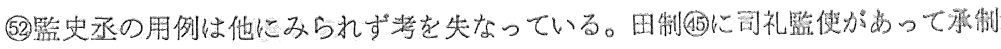

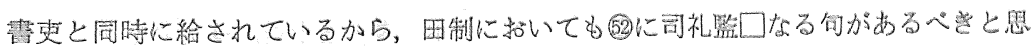
われるが, 今は不明である。

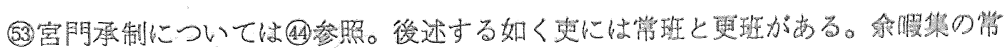

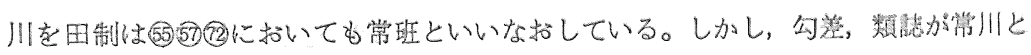

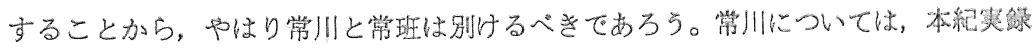

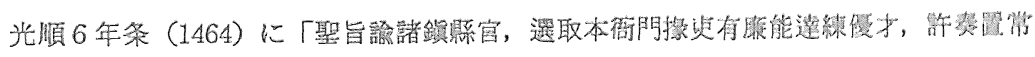

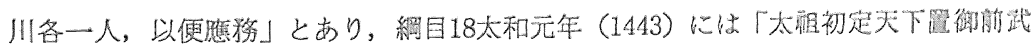

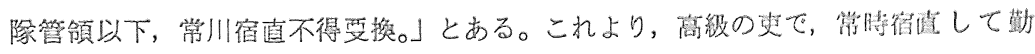
務するものを常川としたと考えることがでさよう。窝制其例 5 にも常川筧人の名がみ える。 


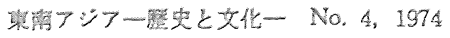

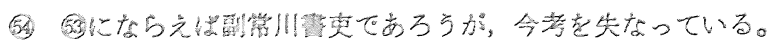

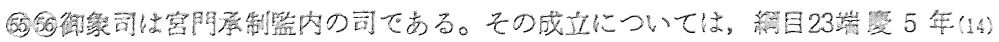

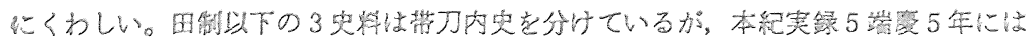

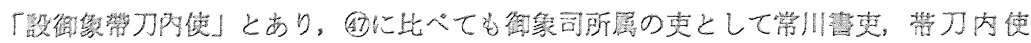

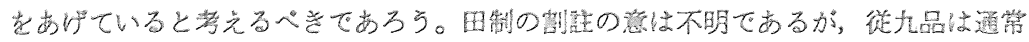

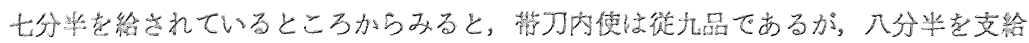
し, 以下同じの竞であるらか。

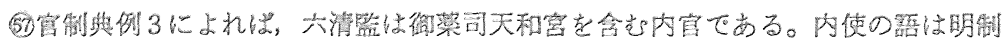

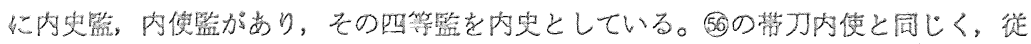
九品の下紋官の名と考光るぺきであるう。

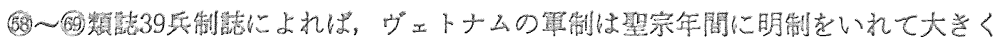

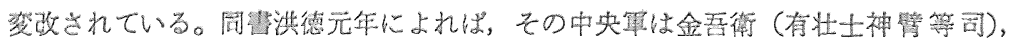

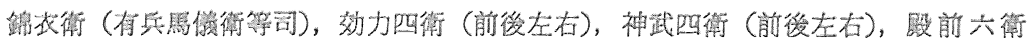

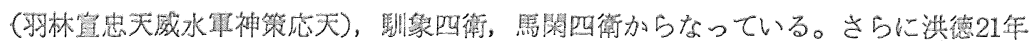
(1490)，端度 2 年（1506），洪德元年（1509）に幾つかの改正がなされた。しかしそ

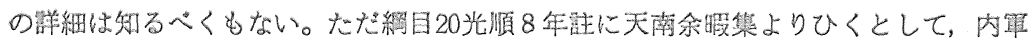
官制が矅列してある。また筧制與例5にはかなり後代のものと思われるがややはり内 策官制が跑されている。ここではこれらを參都にして軍写の比定を行なってみる。

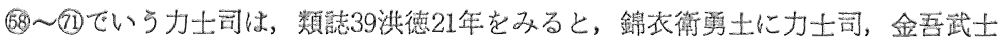

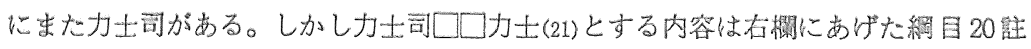

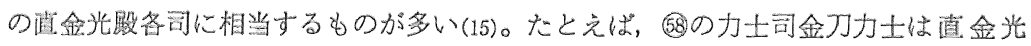
䖉金刀司力士にあたる如くにである。金錦二衛に並んで㨁金光殷各司がいつ成立した かは明らかではないが, 網目 25 端鹿 5 年に「警制金光䖉力士十司, 每司力士一百人, 博士二人，要班奉直金光殿」とあるからこの年以前，おそらくは橴德年間の数次の

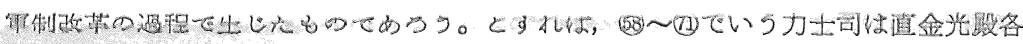

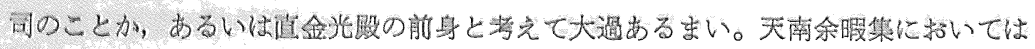
(88969)の例しかなく、また6は他史料にみあたらないが(16)これは直金光毁十司が

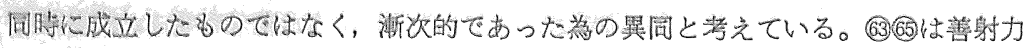
士か゚正しからうがこれも綱目20中にはない。洪順元年（1509）賽刀司の成立した際に 吸收された多のですからか。

(01月制の及に残る侍近戦士末管同の句は不明であるが，(20)下からみると侍近は宫

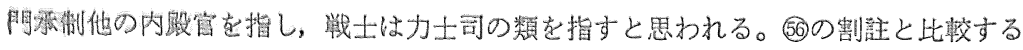




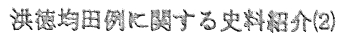

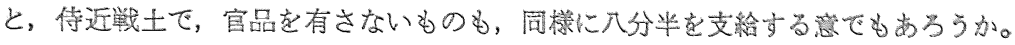
(11)筜略。

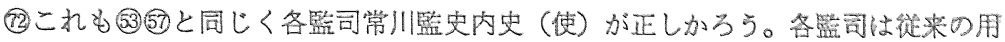

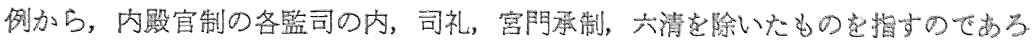
う。監史は各監の吏と考えてよかろう(17)。

(3)先ず後 3 史料を考えると, 勾差でいう咸士は他史料比用例加ないから, 武士の㩆

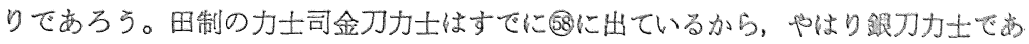

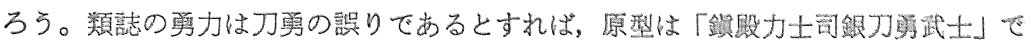

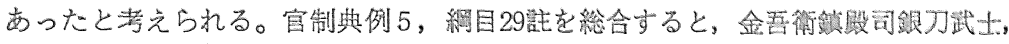
錦衣衛銀刀司等士の称であろう(18)。

(74) (73)の例にしたがえば，力士司捉生(19)勡武士が原型と思われる。金玨繥に力士 司捉生武士，錦衣衛に捉生司筫士の名がみえる。

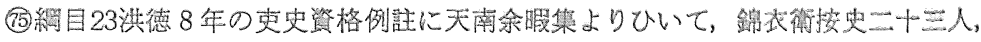

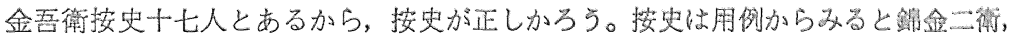
廷尉司に配属された吏の称と思われる。

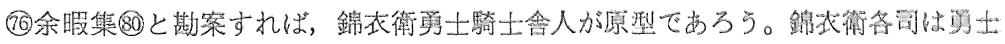
壮士によって棈成されるが，㱦士なる文例は他にみあたらず赫克失なっている。食人 は宫制典例錦衣衛所属の各司壮士の内，伏波司禽人司に常川禽人が，また种威司瓜騎

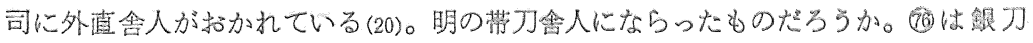
捉生以外の錦衣衛の学士，㱦士，舍人夌指すとみてよかろう。

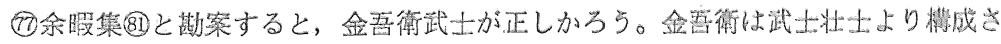
れるが，武士には十四司がある。

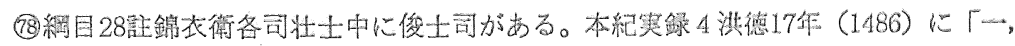

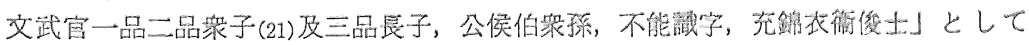
いるから，俊士は特別の家柄の出自支もつものであった。田制と勾壆は俊力士として いるが，俊士司と力士司の雨省の意か。

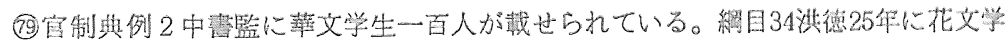

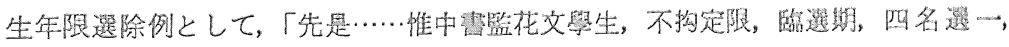

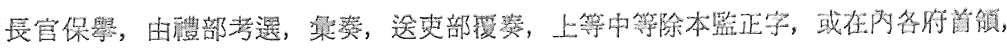

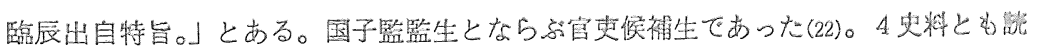

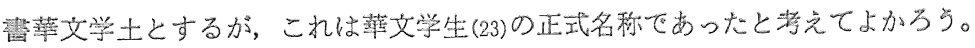

82にいたる史料間の位置内容の翼同については今考を失なっている。天和宾九仙窝 


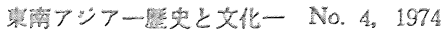

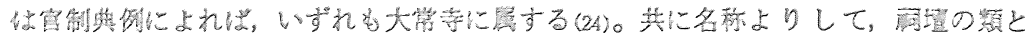

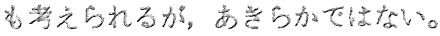

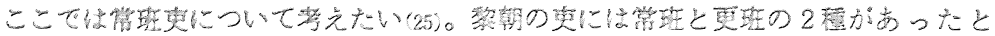

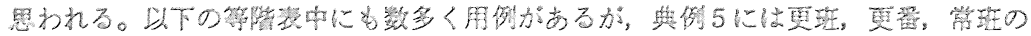

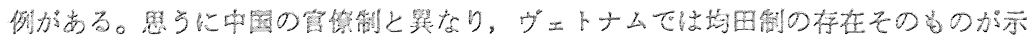

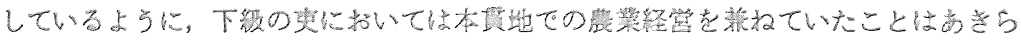

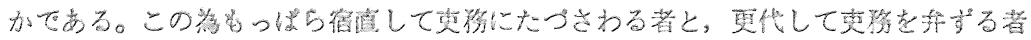

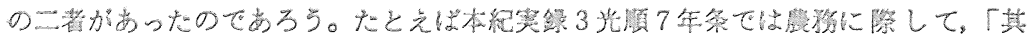

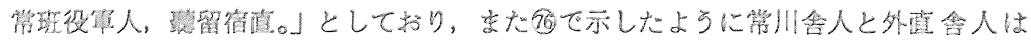
悋礼している(26)。

(9)此略。

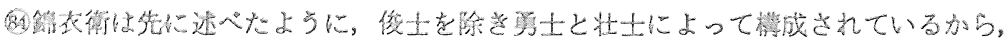

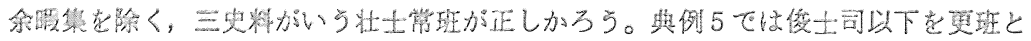

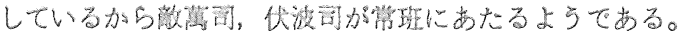

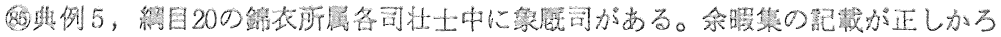
50

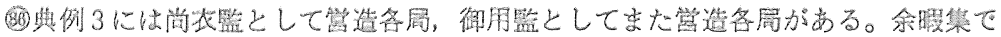
いら御用尚在二監各呞加正しからう。

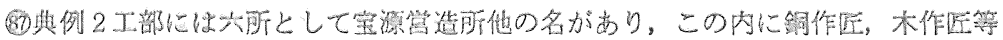

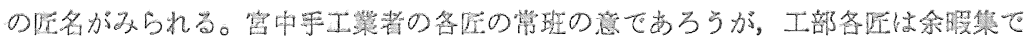

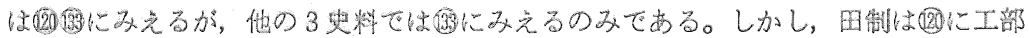

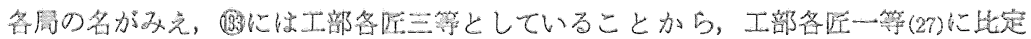

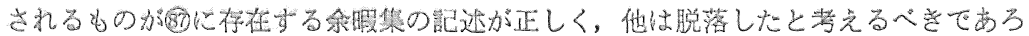
5。(120)

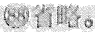

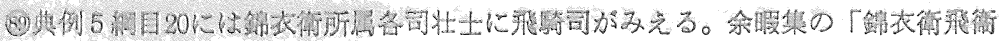

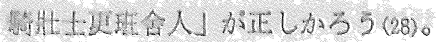

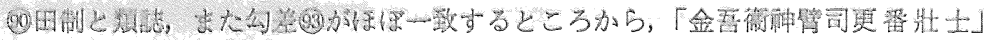

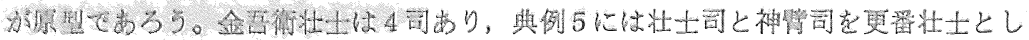
Cis $(29)$.

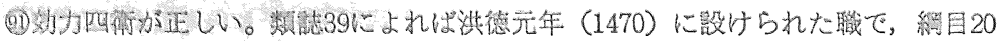

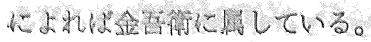




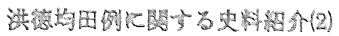

29神武四衛が正しい。

23省略。

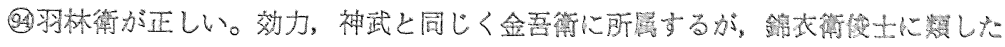

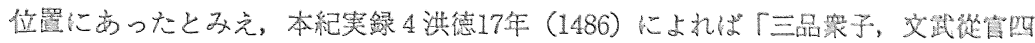

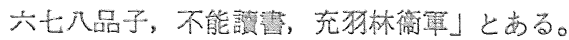

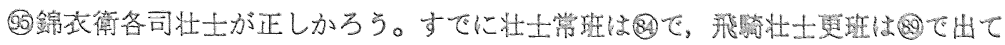

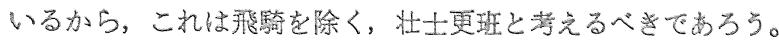

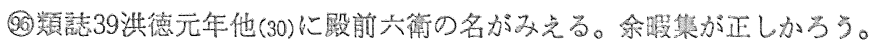

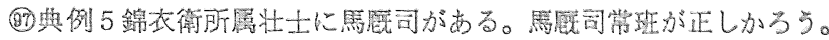

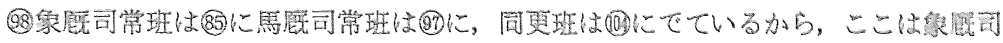
更班とすぺきであろう。

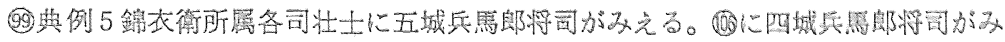

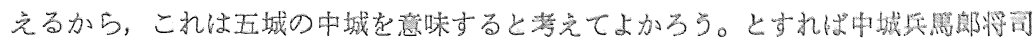
が正しからう。

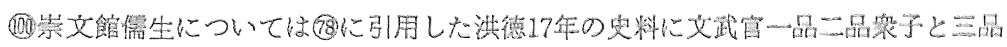

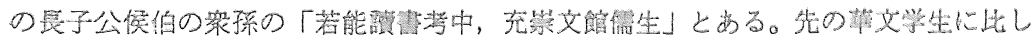
て，一級下位の学生だったのだろう(31)(32)。

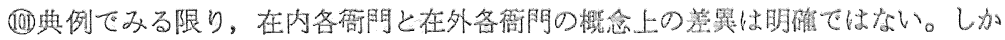

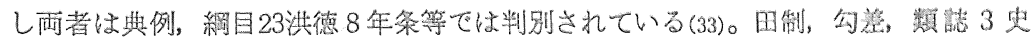
料の在内各衙門都口吏は都提吏，または都题更が正しからう。部果提速（题专）につ

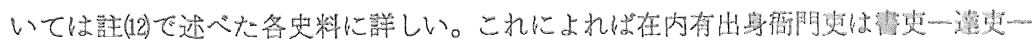

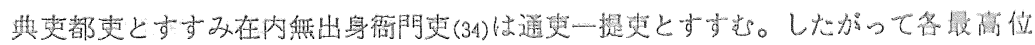

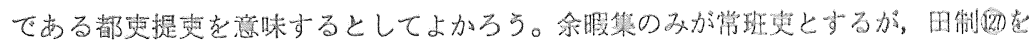

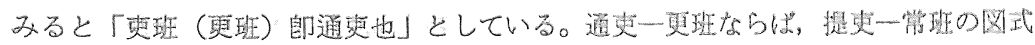

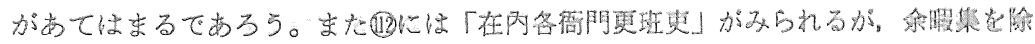

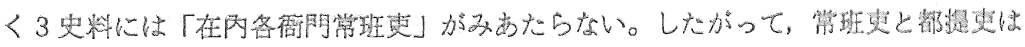
内容的に同一のものてあろう。

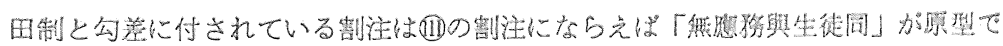

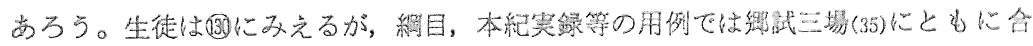

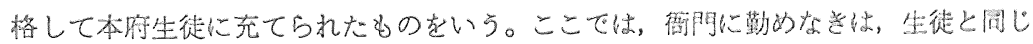
く由六分起給すとの意であろう。先号(100田制武官退一分に対すると思われる。

(10国子監には監生の上に舎生があった。類誌19洪德15年（1484）納目23洪德14华 


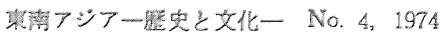

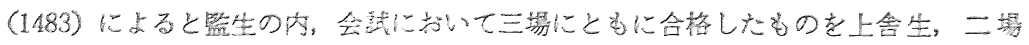

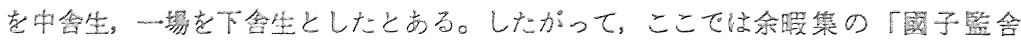

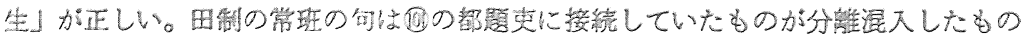
であるう。

侮得。

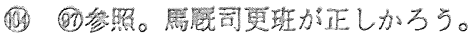

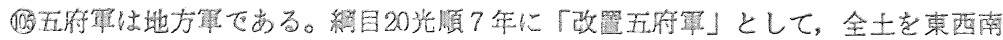

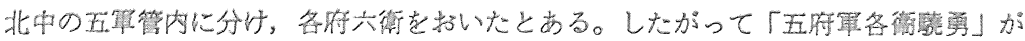

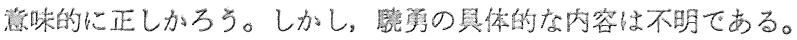

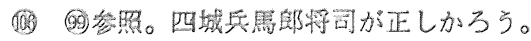

(iii)垈略。

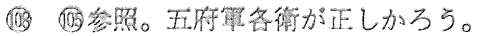

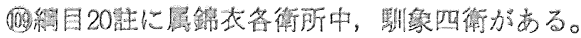

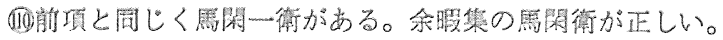

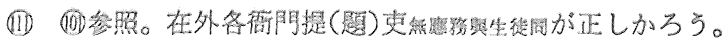

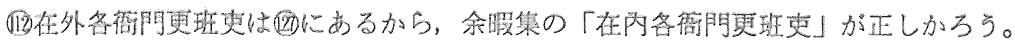

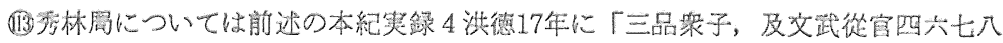

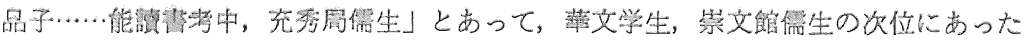
こと坴している。

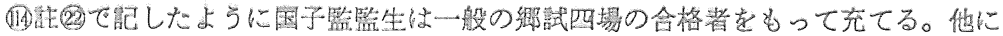
絧目23洪徳14年（1483）に詳しい。

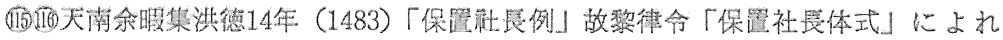

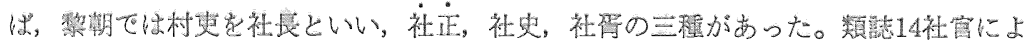

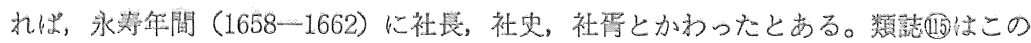

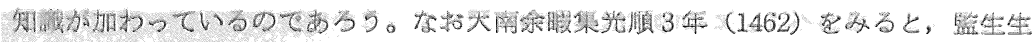

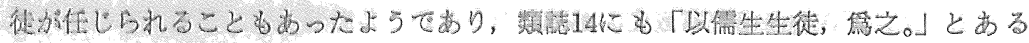

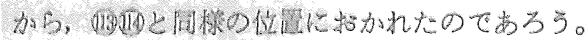

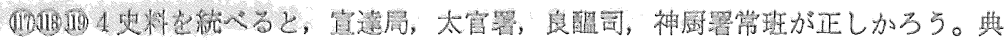

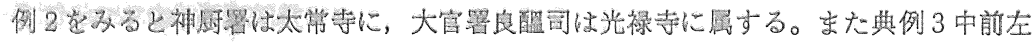

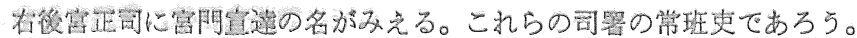

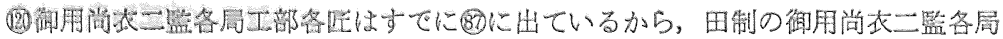

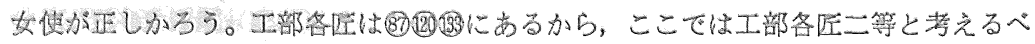




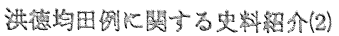

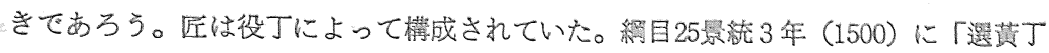

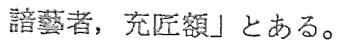

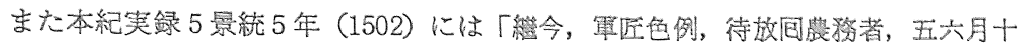

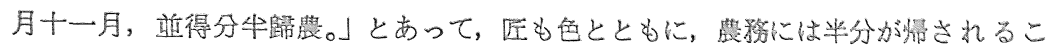
とになっている。

(22)舀路。

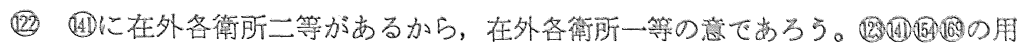

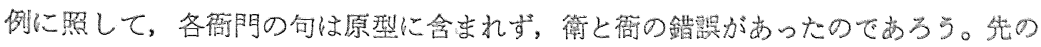
五符軍は六衛よりなり，一衛は五六所より，一所は 400 人の兵丁よりなっていた。こ こではこの衛所軍支さすとみてよかろう。

(29)在内各衛所性に三等肪あるから、ここでは二渻と考光るのがよからう。在内各 衛可一等にあたるものが，これ以前にみあたらないが，怙そらくは馿象四衡，羽林衛 の類が比定されるのであろう。

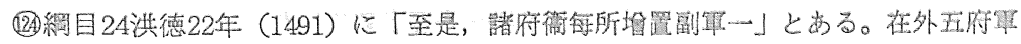

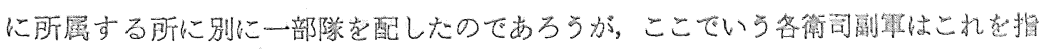
すのであろう。

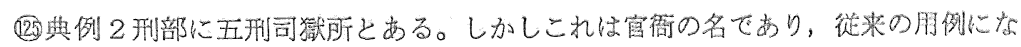

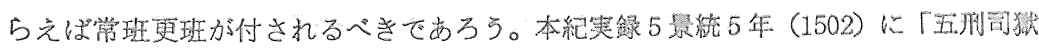

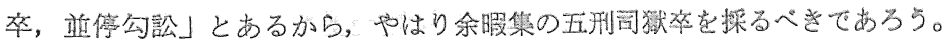

(23)省略。

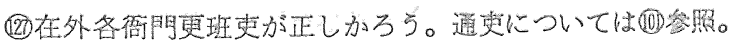

(23) (15)公照。

(29)舀略。

(30)本附生徒のことであろう。(10)參照(36)。

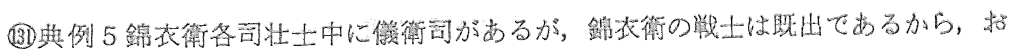

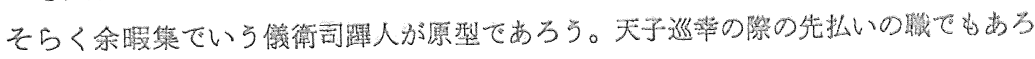
うか。

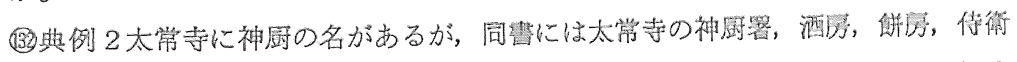

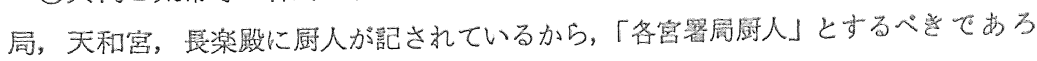
う。幽に二等とあるから、これも一等の意であう。

(33工部各匠は迥で述べたように三等とするのが正しからら。

(34)舆例 2 教坊司に雅楽㦛, 同文署がみえる。雅楽同文二署が原型であろう。これら 


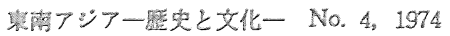

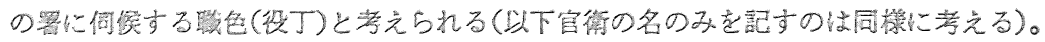

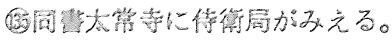

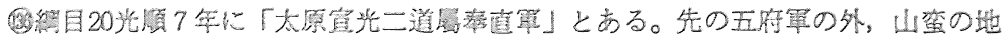

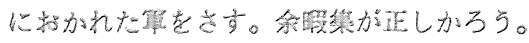

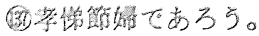

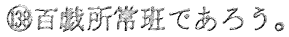

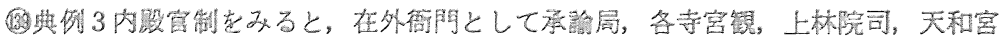

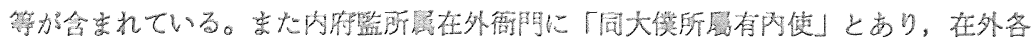

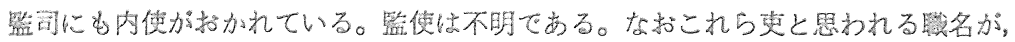
由五分半という低いランクに出ているのは疑間である。

(100) 出略。

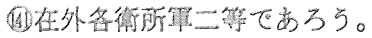

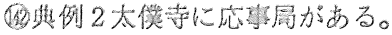

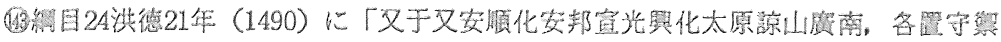

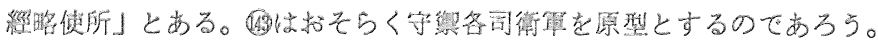

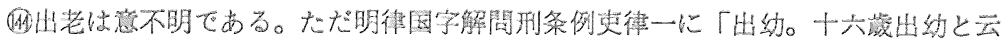

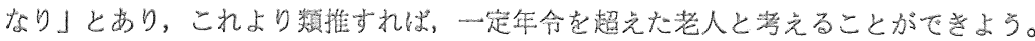

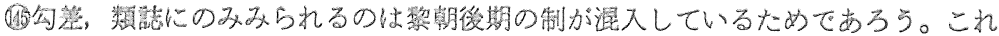

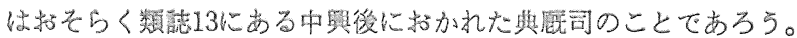

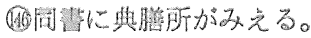

(19)筧撙。

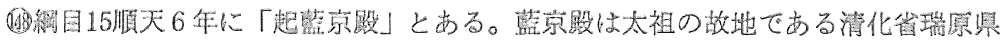
藍山社にある。この地には黎朝諸帝の嘲所があり，行幸の殷が設けられていた。これ に勤仕する备色の意であろう。

(10) (12)

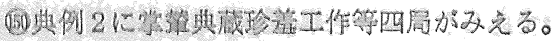

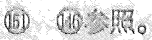

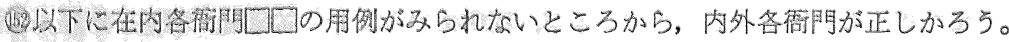

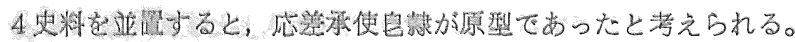

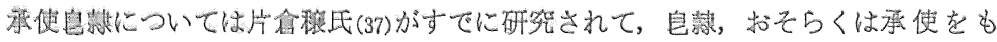

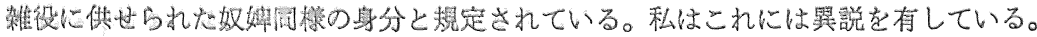

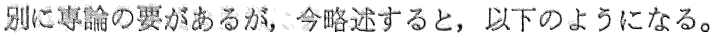




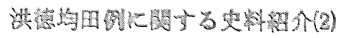

第一に避で四者が並記されていることは身分的に同一匹あると装えられること。第

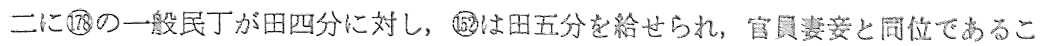

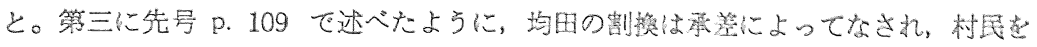

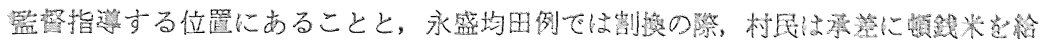

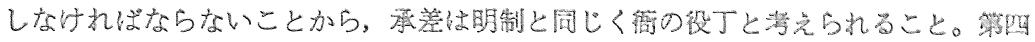

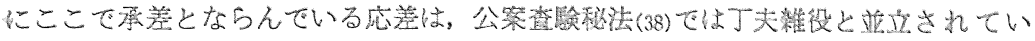

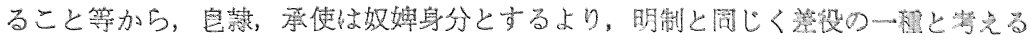

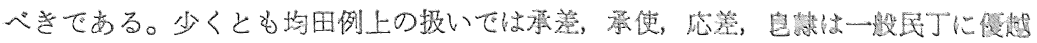
した位蹎にあったと理解される。

邀省格。

(50.在内名衛所軍三等が正しからう。

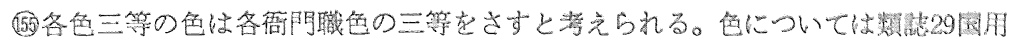

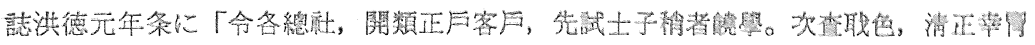
(39)。次閴人丁。」とある。一般人丁から徵收された役丁と理解すべざあるる。

(550省略。

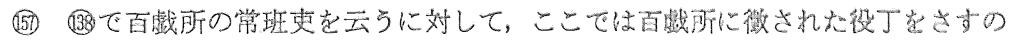
であろう。田制, 勾差に残る教坊は教坊司の意で学らう。

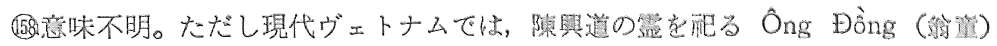

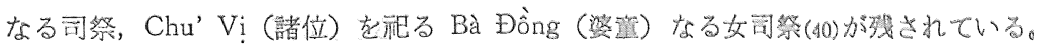

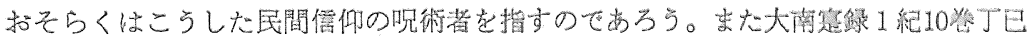

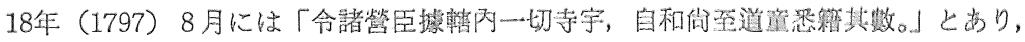
寺宇に奉仕する寺筑の意加とも思われる。

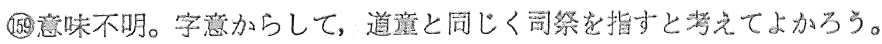

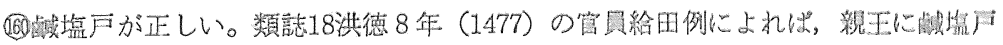
100人が給されたのをはじめ，悬族梅貴にはこの月が等倩に芯して給されている。特 程技能をもった役丁の一程と理解すべきであろう。

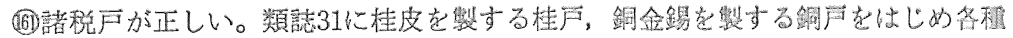

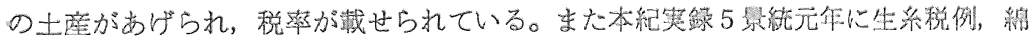

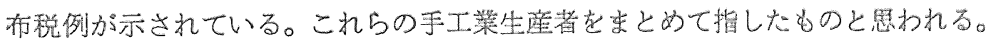

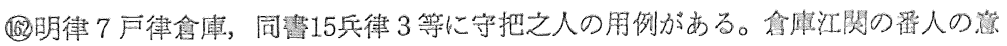

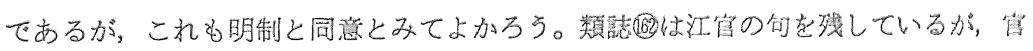
制典例に江官か゚みられ，巡撿使（正九品）以下の賏名が名られる。これより，江官寺 
東荫アジア一歷史と文化一 No. 4, 1974

把人，または江官守把軍が原型であって，江官に属する番人と考えてよかろう。

(169616漁業を営む戸であろうが，内容は不明である。

(69.意味不明。

(66)黎朝諸陵の管理人であろう。

(16)見存の洪德版図には牧馬鎮賞図なるものが付されており，高平鎮城の近くにあっ た牧馬城の図がかかれている。黎朝馬政についてはまったく不明であるがこうした 牧馬鎮もしくは牧馬城がおかれていたとすれば, 当然牧丁の存在も考えられる。京人 は現代ヴェトナム語では Ngu'o’i Kinh (人京) として，ヴェト人のことをいうが， どう䦭連するのか考を失っている。

(168)少略。

(69)在外谷郝所军三等であろう。

(10明律国字解問刑条例工津河防に「舖夫は番所につとめる人夫なり」とある。

(111)原型は館駅夫であろう。筑集天南四至路図晴(41)をみると，全国の道路，河津の いたるところに㜚某なる地があり，さらに旅程表中にも館宿某なる記载が散見する。 馆とは宿駅であって，馌駅夫とはこれに勤める役丁の類をさすとしてよかろう。

(172泫は罣の略字であろう。堌峝寺钼の夫の意としてよかろう。

通採蒋夫は浆草採りのことであろうが，内容は不明である。

(114)池涩夫が正しかろう。内容は不明である。

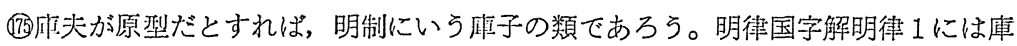
子はくらぼしなりとしている。倉間の翻人である。

(176)它味不明。

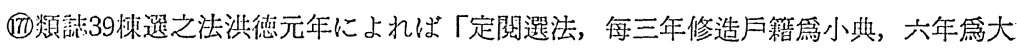

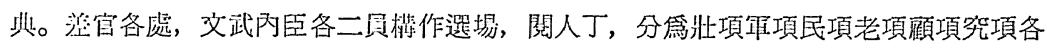
等。家有三丁, 一補号(42)壮, 一補项項, 一補民項。四丁, 二補民。五丁六丁以上,

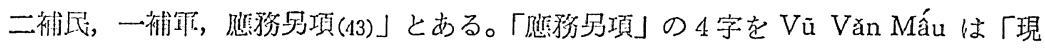
に价陊につく hạng lính」と訳出している(44)。上文中にはまた号壮の二字がみえる が，これについて網目19光順 6 年は「壮项, 充可伍, 㮣䓉者, 謂之壮項。」としてい る。これらより，号壮，または壮項は現役当仕の兵丁と思われるが，では同文中の軍

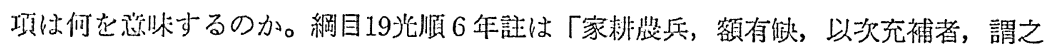

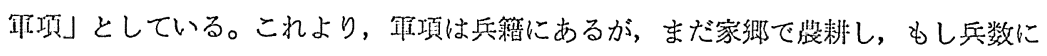
欠むる場合，徽集世られるもの指すとみてよかろう。四でいう軍色も上述にならえ

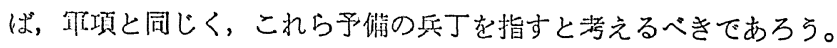




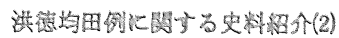

(19)無色は色役に徴されていない丁の意であろうから、一般民丁と教えてよかる5。 揢注は意味から推して，優兔丁同が正しい。

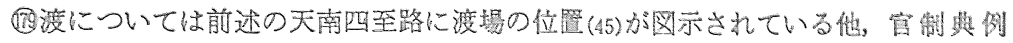
2 江官には渡㔻の役名がある。渡船㔠の人夫の意でるう。

(190)省略。

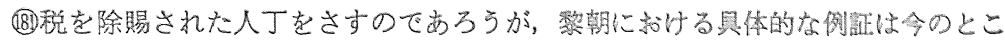
ろ, 兒出していない。

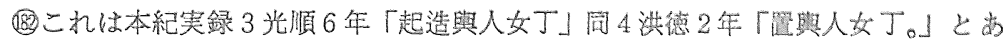

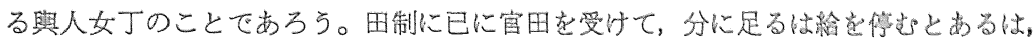
侍近の官と同じく、私的な受田が多かったからであうう。

(193)省略。

(18)田制回能照。

(189)省略。

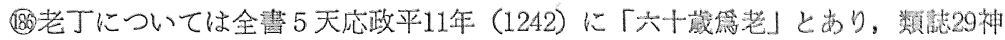

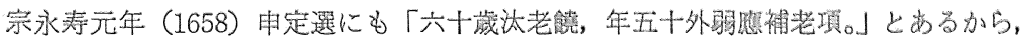
六十歳以上が正しからう。

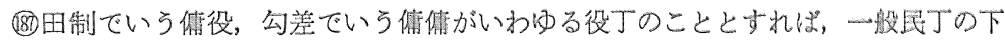

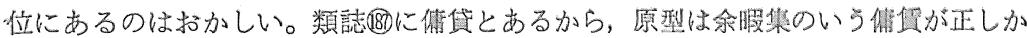

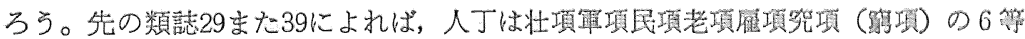

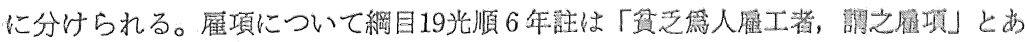

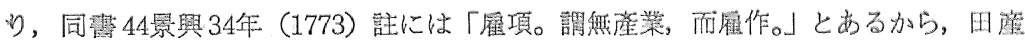

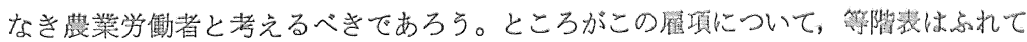
いない。怙そらく字㼁からすれば,この侓貸が㕍項に比定されるのでるら。

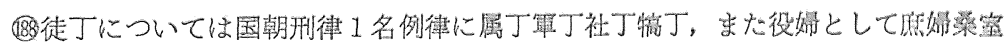
婦が記されている。徒各丁，役媂同が原型であろう。

(19)省略。

(199)田制回参照。

(91)残宛であろう。

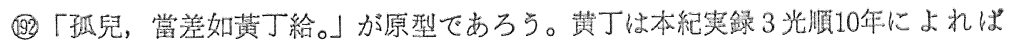

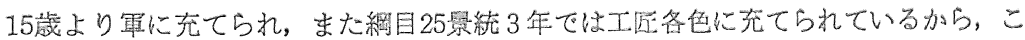
れ以外にも一般民丁と同じく，培筑(46)の如き将役に美されていたと考えられる。こ れに参加している孤児は黄丁と同じく田三分半を給するというのであるう。 


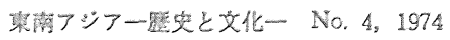

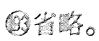

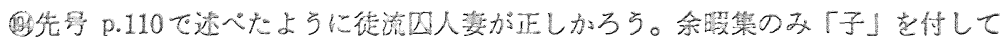

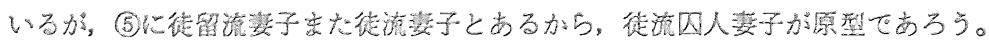

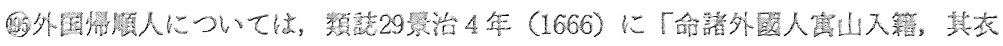

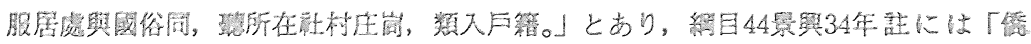

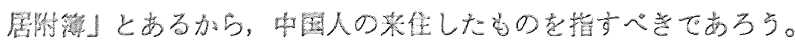

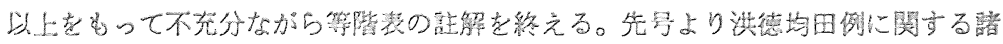

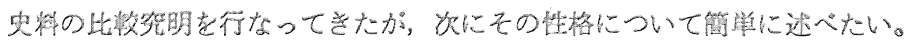

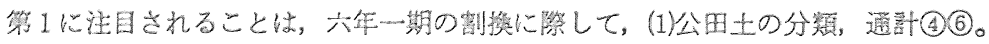

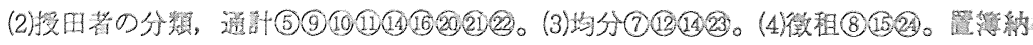

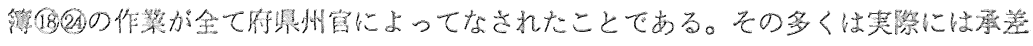
によってになわれたとしても，少なくとも法文上は，府眼官の任弱となっている。

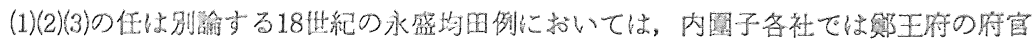

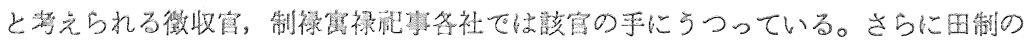

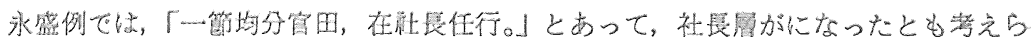

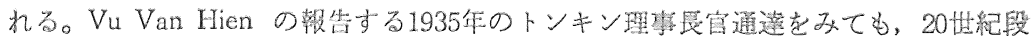

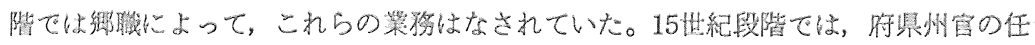
ですったことは注目ず゙゚である。

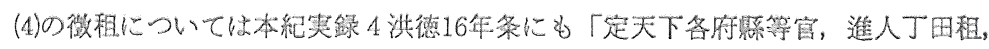

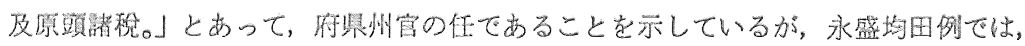

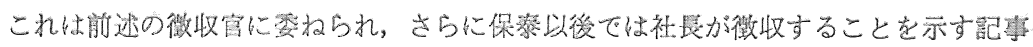
が埥見している(47)。

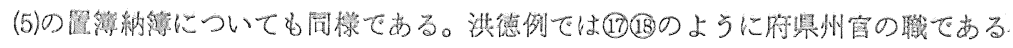
が, 永盛例ではこれは徵收官の僟である。19世紀末で, 公田は Sổ hàng xa (数項补)

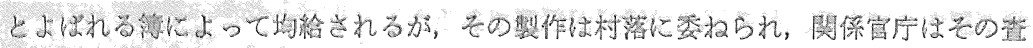
然艺していない。

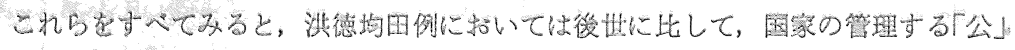

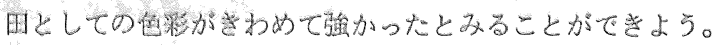

戏に公由の存在理由について考去る。

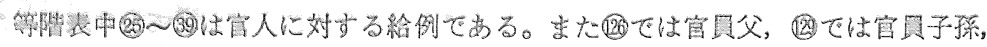

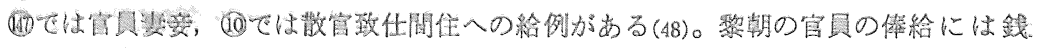

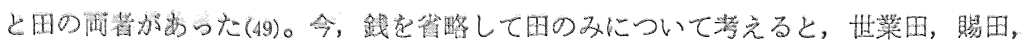




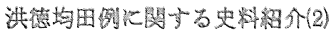

祭田、それにここでいう給田に類別される(50)。この内，世業田は栄封伯妾てであり，

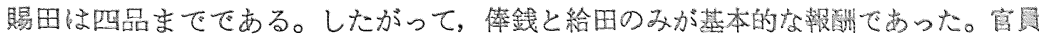
の俸給としての給田は永盛例，噗隆例においてもうけつがれるが，明命20年(51) (1839)

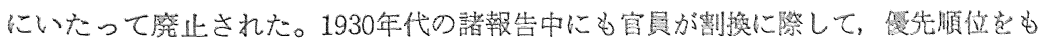
つことを記してはいるが，特に田克給されるということはないようである。したがっ て洪德例に求いても官員の俸給としての給田の意味は大きい。

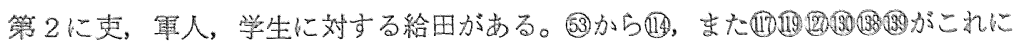

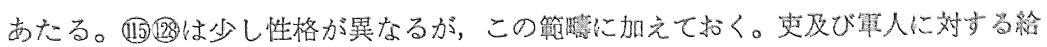

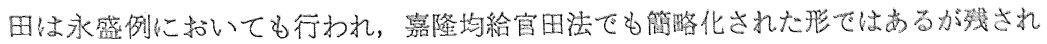

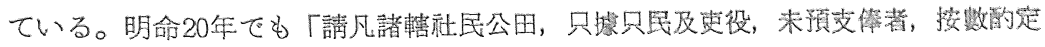
均給」として，俸酯を得ていないものについてのみ均給されることが述べられている。

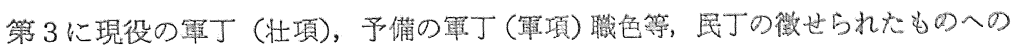

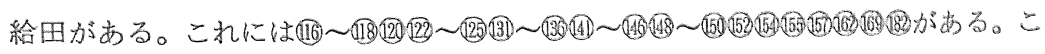

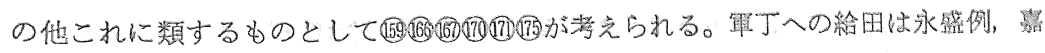
隆例, さらに明命年間で残されている。しかし, 黎朝後期以降では口分田, 阮朝て は糧田が主流となっている。鼠田は lu’o'ng điền, また ruộng lính として20世紀 で残されている。口分田，糧田も公田の一部分から支給されるが，受田数が固起され

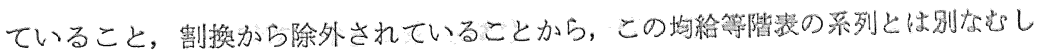
ろ田禄の延長上につらなると考えるべきであるう。とすると，軍丁，職色への代橵が 公田より，均給例の一部としてなされたことは，洪德均明例の大さな特色と考克る とができる。

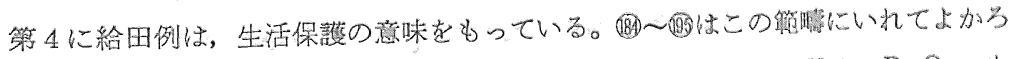

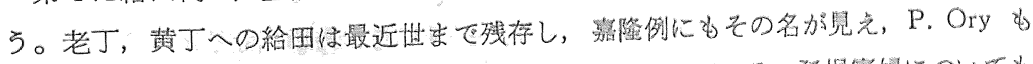
hoàn đinh lão làng は通常壮丁の半ばを受田するといっている。孤胃察婧について cô-nhí quã-phủ に対する給田の存在を報笘している。しかし，その性格は投近批て は共同体内部での相互扶助の惯例として残存しているにすぜな。この面て, 港德例

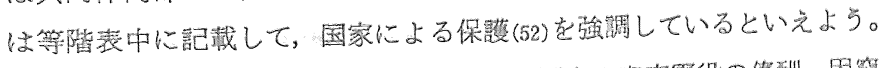

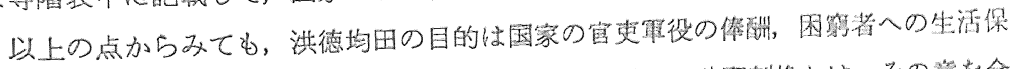

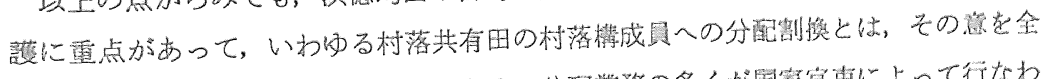
く輁にしていると考えられる。しかもその分配烣務の多くが国家官吏によって行なわ れ，さらに先号で述べたように公由のみが課租田であったとすれば，淡德均田例下の 公田は、まさに国家の田であったとみることがでさよう。 


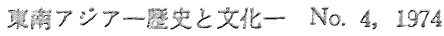

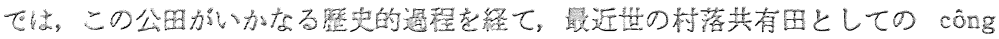

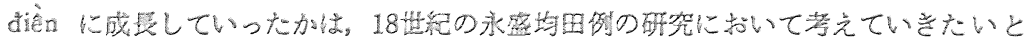
隐5。

（邀络先

怔

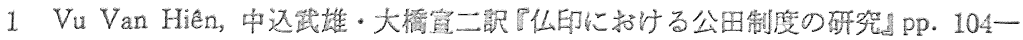
25.

2 ibid., pp. 169-170.

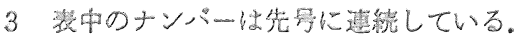

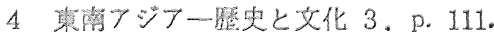

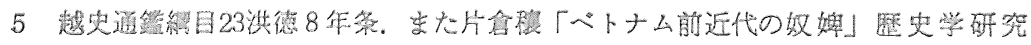
356に紹介されている。

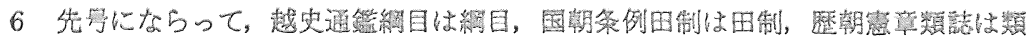
誌，国朝富制典例は宦制與例と略即する。

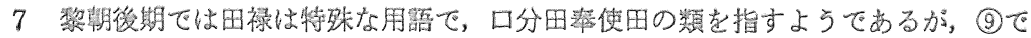
いう田祿はより広督であると理解したい。

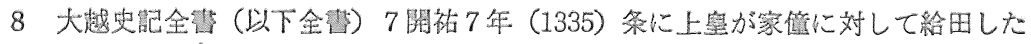
例がdる。

9 R. Dumont, La Culture du Riz dans le Delta du Tonkin, Chapitre III.

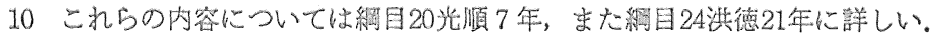

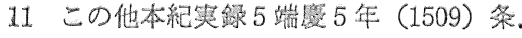

12 他に絧目22洪德 8 年「定更史筫格令」踥，宫制典例 4 洗德年間吏資格諸例にほほ

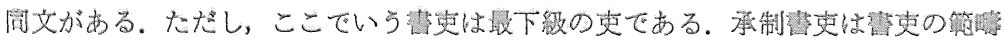

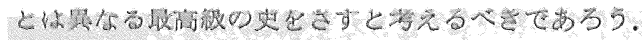

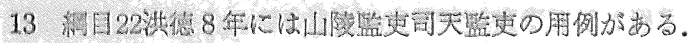

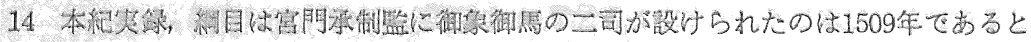

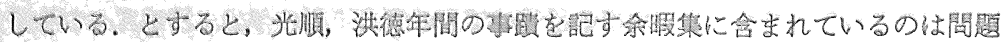

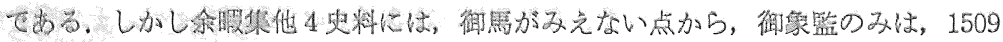

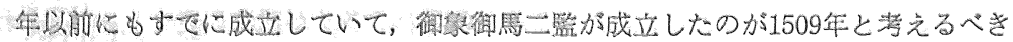
s.马しれない.

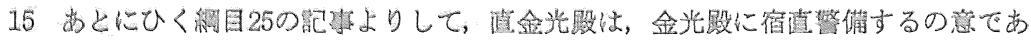
120 
ろう.

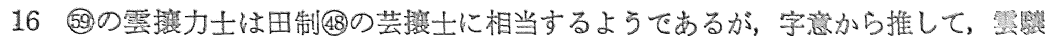

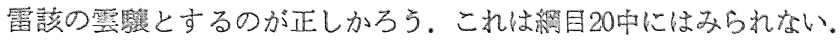

17 註13参照.

18 前述のように官制典例 5 も絧目 29 子かなり後代の西制と考えられるのて，均田例 の時期には銀刀司は鎮殿力士司に一本化していたのかもしれない。

19 捉生は捕虏索捕える意. 銀刀, 捉生は, 他の錦金二幑各司に比して俊越していた のであろう。

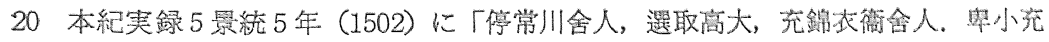

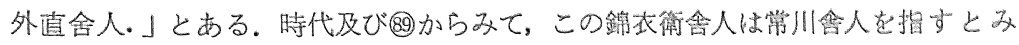
てよかろう。

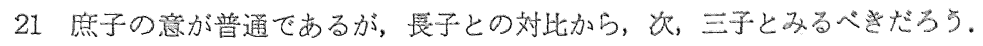

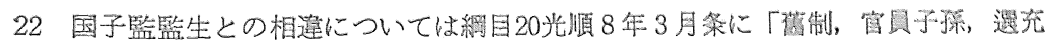
御前近侍局學生生徒. 鄉職中四堨者均充國子監監生.」とあり, 官具子躬起学生生 徒，楖試四場の合格者を国子監監生としたことがわが。

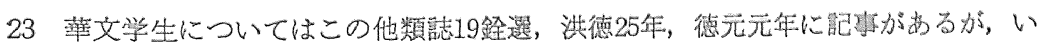
ずれも赫文学生としている。

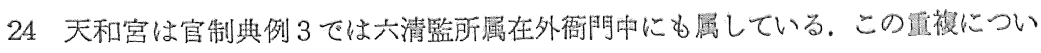
ては不明であるが，名称より判断すれば，祭苚克学る太常寺折属が正しからう。

25 類誌820布班は常班の䛊りであろう。

26 (89)をみると, 稳騎壮土は更班舎人となっている。典例 5 ではこれらの司には外㨁

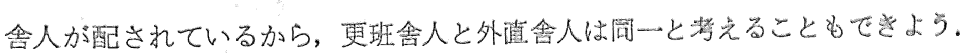

27 (22)で記すように，各色に三等の別があったようである。均田例文では通常一等いま 記されず, 二等三等のみが注記されている。

\section{8 註26参照.}

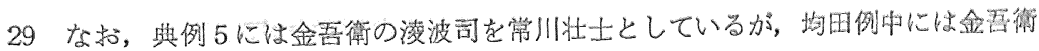
壮士常川の名がない.疑閏である。

30 前揭の他には網目 22 洪徳 2 年 (1471) にみえる。

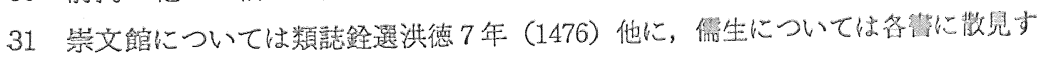
る、学生 (萍文学生), 霹生, 監生（国子監監生）と列唀されることが多い。

32 基伝として䋚目23洪德 8 年 (1477) 申定宫員子孫遙用例がある。ここでいう旧制

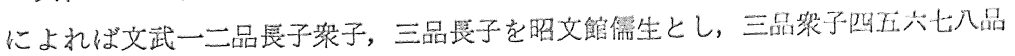




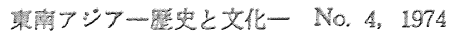

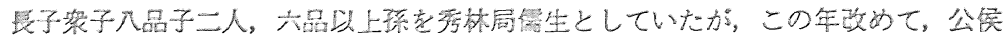

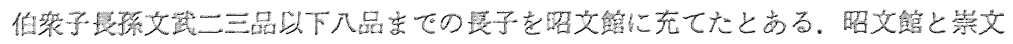

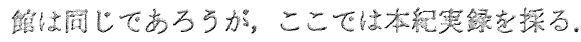

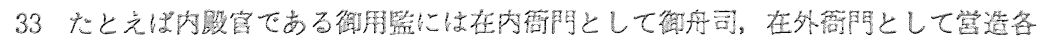
呞があ。

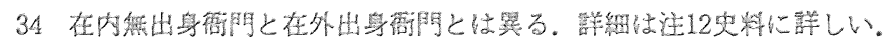

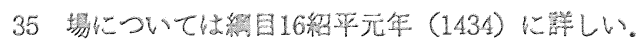

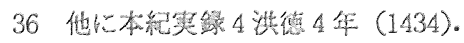

37 片倉旅 op. cit. p.24.

38 皆奇, p. 115 嗝 11.

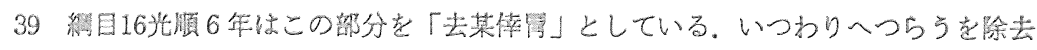
するの意であろう。

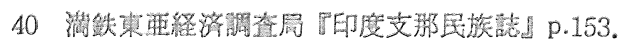

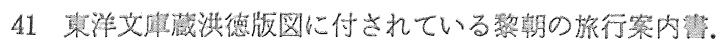

$42 \operatorname{linh}$ 兵の总.

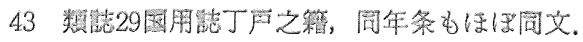

44 Vũ Văn Mấu, Lịch Triè̀u Hiến Chu'o'ng Lọi chí, Saigon 1957 p.377.

45 この他, 数讀 316 巡渡之税か゚詳述されている。

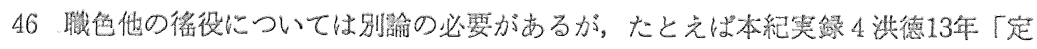
築田界等永令.」に「督很居, 培筑田界.」とある。

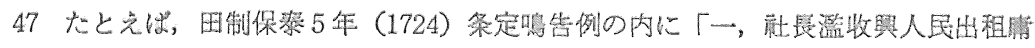
調錢」とある。

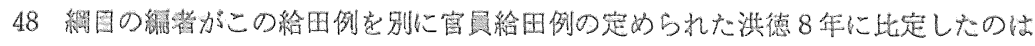
このゆえでる。

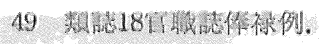

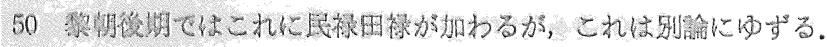

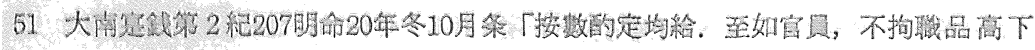
pher.j.

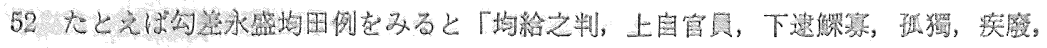

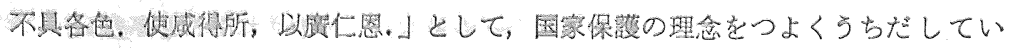
b. 